\title{
Complexity, Uncertainty, and Monetary Policy: Can the ECB Avoid the Unconventional Becoming the 'New Normal'?
}

\author{
${ }^{1}$ Bournemouth University, Poole, United Kingdom of Great Britain and Northern Ireland, E-mail: chartwell@kozminski.edu.pl. \\ https://orcid.org/0000-0003-3340-1276. \\ ${ }^{2}$ Kozminski University, Warszawa, Poland, E-mail: chartwell@kozminski.edu.pl. https://orcid.org/0000-0003-3340-1276.
}

\begin{abstract}
:
Worries about Italy and the unresolved issue of euro governance - coupled with uncertainty surrounding Brexit - means that the European Central Bank (ECB) may already be facing its next crisis in the euro area. Unfortunately, the ECB is still fighting the last war, deploying the tools of unconventional monetary policy to address lingering problems while unable institutionally to address needed structural change. This paper looks at the ECB as an institution amongst institutions and shows how even more unconventional approaches will not help to bolster the economy of the euro area. Indeed, given the complexity of money, the effects of expectations, and continued uncertainty, expanding the ECB's unconventional arsenal is likely to have deleterious consequences across Europe.
\end{abstract}

Keywords: complexity, euro, European Central Bank, monetary policy

JEL classification: F33, F15, F45

DOI: $10.1515 / \mathrm{ev}-2019-0021$

\section{Introduction}

By many metrics, the euro area has stepped away from the brink of disaster it faced in 2011 and 2012 and is in the midst of an economic recovery (even if the recovery is unimpressive). Across the 19 euro area countries (EA-19), unspectacular-if-steady growth has returned (Figure 1), with smaller countries such as Ireland and Malta leading the way (6.7\% and 6.6\% annual growth rates respectively for 2018) and the core large countries of Germany and France seeing relatively more modest growth (at $1.4 \%$ and $1.7 \%$ respectively in 2018). From a monetary policy standpoint as well, the omnipresent worries of the European Central Bank (ECB) of disinflation leading to deflation have also abated, with the EA-19 seeing rising prices since June 2016 and figures from October 2018 showing inflation of 2.3 percentage (in line with ECB targets, although inflation has come back down to 1.1 percentage in July 2019). With gross fixed capital formation surpassing its pre-crisis levels in Q2 of 2017 and rising steadily and consumer confidence at its highest levels since the early 2000s, it appears that the worst of the dual economic catastrophes to hit Europe over the past decade has passed.

Despite this apparent trend away from crisis conditions, however, for the most part economic policymakers in Europe (and first among them the aforementioned European Central Bank) remain on a crisis footing. In the first instance, this may be because the euro area crisis appears ready to flare up again. While the long-term viability of the euro seems much more assured than it did just 5 years ago, unresolved issues regarding the European Monetary Union's (EMU) architecture, and in particular the fiscal aspects of the union, continue to plague the currency union. As in 2010 and 2011, these concerns are once again centred on the euro area's southern countries, with Italy's skyrocketing sovereign debt (approximately 145 percentage of GDP) and promises from its government for additional fiscal profligacy the largest cloud on the horizon. Given the size of Italy and the impossibility of a successful bailout along the lines of Greece, the efficacy of the ECB alone in confronting the possible destabilising effects of Italy's current path is called into serious question. 


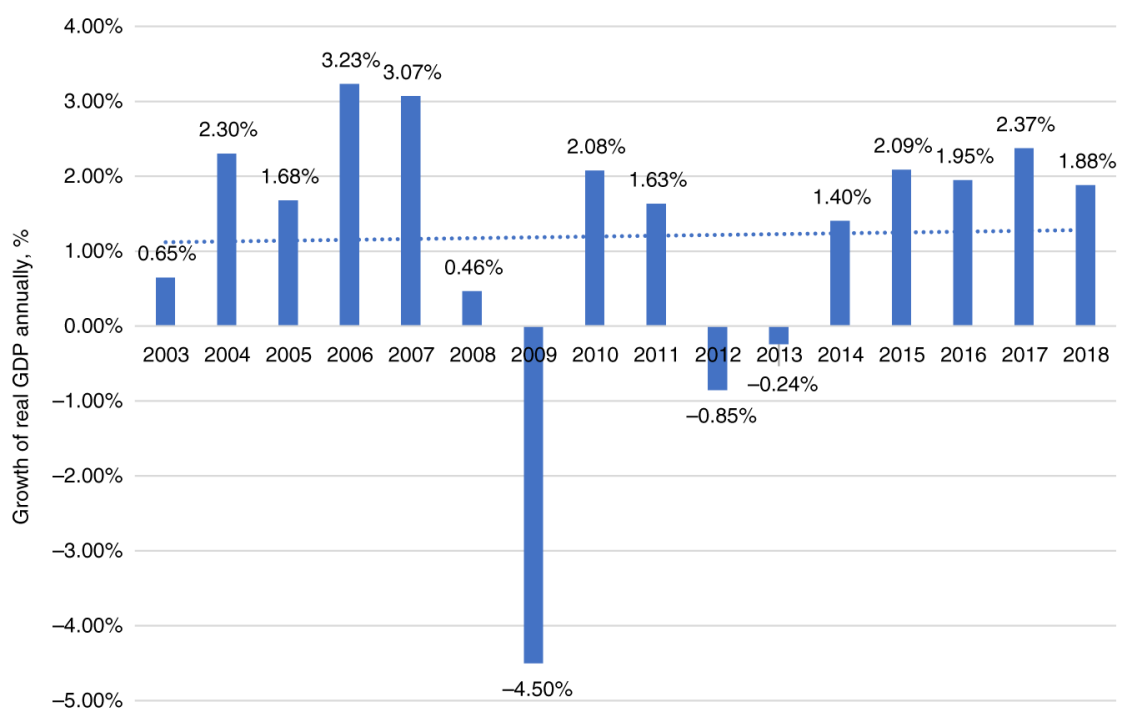

Figure 1: Growth in the Euro area 19, 2003-2018.

Source: Calculated from Eurostat data, chain-linked GDP at market prices. Eurozone includes all 19 current members of the common currency. Trend shown as dotted line.

This issue is compounded by the reality that the ECB was (and is) a slower-moving creature than the US Federal Reserve. In response to the global financial crisis, the ECB acted much later than the Fed, while the euro area crisis seemed to catch the ECB unaware (Figure 2); as also shown in Figure 2, the US Federal Reserve has been more aggressive in its withdrawal from unconventional monetary policy. While the differential economic performance of the two currency zones can explain somewhat the differing policy responses (i.e. the US has had a much more robust recovery than the euro area), there also may be an institutional imperative, as the belated response of the ECB to these crises and the resulting economic damage may have made the ECB cling to unconventional monetary policy for a longer period of time. Thus, a long period of zero interest rates and a belated start to withdrawing from its main unconventional tools (such as the Asset Purchase Programme) have left the ECB with few instruments to tackle the next crisis. Indeed, the exigencies of the euro area and unresolved issues related to its governance (above all on the fiscal side) have meant that, for the euro area, the 'unconventional' has become 'the new normal', but it remains to be seen if it has been and can be 'effective'.

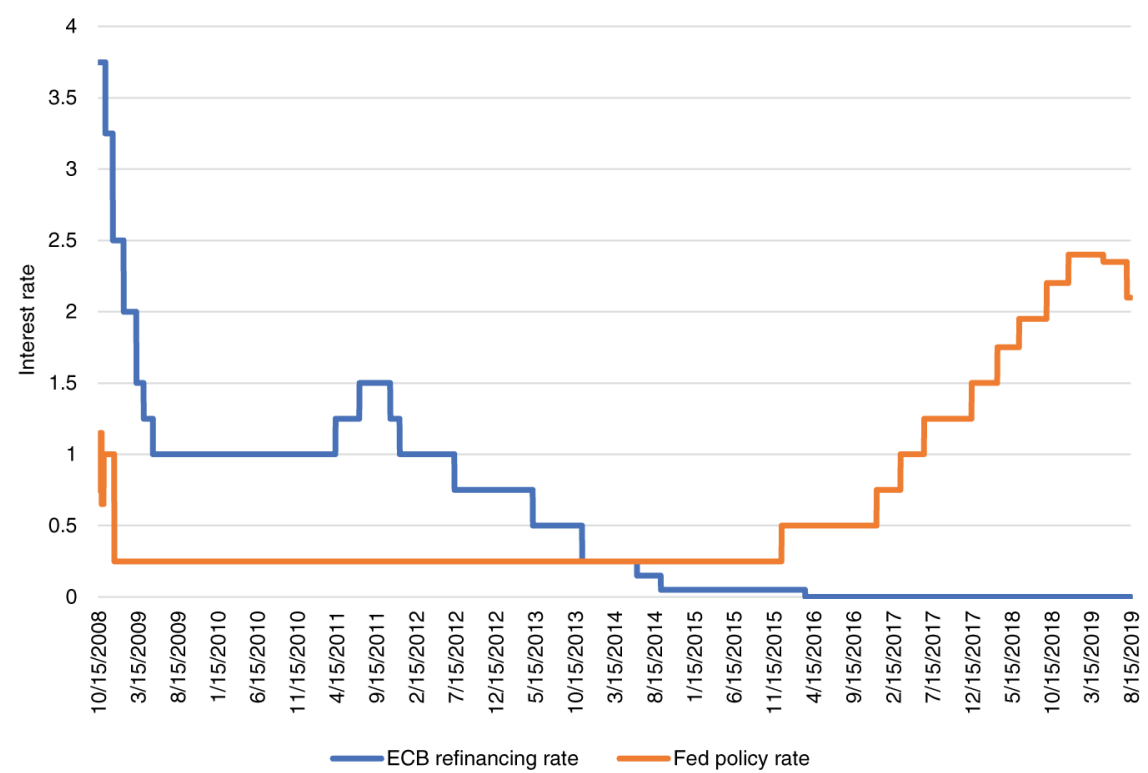

Figure 2: Policy Rates for the ECB and the US Federal Reserve, October 2008-August 2019. Source: ECB and US Federal Reserve.

The purpose of this paper is to take an unorthodox look at the challenges for EMU in the post-global financial and post-EMU crisis world, with a focus on uncertainty, the complexity of monetary policy institutions, and the complexity of monetary policy itself. I argue that the question of the instruments that the ECB has - and if they are adequate to handle the next crisis - is meaningless without considering the effects that those instruments 
and the ECB itself may have had already. In the first instance, I examine the ECB as the central institution in EU monetary policymaking, but an institution which is neither as independent as it claims nor as powerful as it might wish to be. In particular, the ECB is constrained in its own independence by various other actors, including Member State governments and their fiscal policies, markets, and individual expectations, and these institutional constraints impact how the ECB's instruments and tools will affect the euro area as it looks ahead to its next crisis. My main argument is that the same issues which threatened the euro in 2011 never really went away but are reappearing with a vengeance in 2019 and are being addressed via the same philosophical mindset (and the same tools). In this sense, by focusing on the monetary instruments of the ECB we are missing the bigger picture of the institutional problems of EMU.

The second focus of this paper is to understand that even a change of monetary policy tools may not resolve the difficulties in setting an EMU-wide monetary policy, due mainly to the complexity of money. While the ECB may be primus inter pares as an institution for setting monetary policy in the EU, it is both reactive to the business cycle for setting monetary policy and a precipitant of future business cycles. The complexity of monetary dynamics, and especially the reality that current policy decisions alter future expectations and behaviours, may stymie even the best laid plans from Frankfurt. Without taking into account the complexity of money and the endogeneity of expectations, even a massive expansion of the ECB's money creation abilities will have little positive (and likely huge deleterious) effects on the real economy of the euro area; as shown in other research relating monetary policy to institutional development, there may even be an argument that the money creation that has occurred has also led to the deterioration of political institutions within Europe.

The rest of this paper is laid out as follows: the next section briefly examines the actions taken by the ECB in the wake of the global financial/EMU crisis, while Section 3 places the ECB within a web of monetary policy institutions in the EU. Section 4 explores the evidence for complex causes and effects of monetary policy, while Section 5 concludes with some recommendations for EMU going forward.

\section{A Brief Recap of Unconventional Monetary Policy}

\subsection{Desperate Times, Desperate Measures}

In order to understand if the ECB is ready to handle the next crisis, it is crucial to understand both exactly what was done that was 'extraordinary' in the wake of the global financial/euro area crisis and also what effects this approach had on the economy of the euro area. Unfortunately, there is still dispute amongst economists and policymakers over what actually triggered the EMU crisis, making an analysis of its effects problematic. Baldwin and Giavazzi (2015) among others have noted that the crisis of 2010 onward has been more of the start-stop dynamics of capital flow crises than a sovereign debt crisis per se (although they fail to acknowledge that capital may have stopped flowing precisely because it was being handled inefficiently by high-spending governments). Mody and Sandri (2012) somewhat agree but point out that financial stress led directly (with a lag) to sovereign debt stress, mainly because the markets were anticipating large bailouts. Mourlon-Druol (2014) attempts to deflect blame from the euro itself by noting that the issues inherent in the EMU crisis were longfestering within the EU, with the lack of economic convergence a major culprit. Finally, Martin and Philippon (2017), creating a model of several different types of crises (domestic credit, fiscal policy, and current account) note that the culprit for the crisis differed across each country in the euro area, with only lack of fiscal prudence in the boom times and a need for better macroprudential regulation standing out as a common flaw.

With these differing views on what precipitated the crisis, designing a one-size-fits-all response to the crisis faced difficulties, especially given the probability that the EMU crisis was caused by some combination of all of these factors and also given that knowledge of how to stop the crisis was difficult to come by in real-time. Without knowing which factor predominated, the ECB was reduced (as most central banks are) to targeting broader economic aggregates rather than root causes, focusing on broad strokes for the overall economy rather than surgical interventions in specific sectors. ${ }^{1}$ As this paper is not meant to rehash the extensive literature on the ECB's actions over the past 10 years, we will keep the overview of the ECB's unconventional measures limited, but, suffice it to say, it is the scale and breadth of the interventions which the ECB has undertaken over the past decade which allow for application of the moniker 'extraordinary':

- Interest Rates: As shown in Figure 2, the ECB reduced its interest rates to 1 percent in May 2009 and (after a brief rise) below 1 percent in 2012; since July 2012, it has maintained rates at or near zero, an unprecedented occurrence in the history of the Bank but one in line with other central banks around the world. Indeed, the ECB went one step further in reducing its deposit facility rates into negative territory in June 2014 and further into negative territory throughout 2015 and 2016 (where they remain). While use of the interest rate channel is not exactly 'extraordinary', abnegating the time value of money as a persistent official policy was indeed 
a major step and one which was unprecedented at the time for such a huge economic area (Switzerland had done it first in 2014, following on from an experiment in the 1970s, but the euro area is quantitatively and qualitatively much more important).

- Qualitative easing: Beyond reducing interest rates as far as they could go (and beyond!), the ECB undertook a series of interventionist measures aimed at changing the composition of its balance sheet. As Jäger and Grigoriadis (2017) note, qualitative easing was used mainly during the global financial crisis and was targeted at financial institutions (above all banks): the instruments used included de facto unlimited overnight liquidity, temporary currency swap lines with the US Federal Reserve, and supplementary longer-term refinancing operations (LTROs) with maturities far exceeding those normally in use (see Lenza, Pill, and Reichlin 2010 for a more in-depth explanation).

- Quantitative easing: More concentrated in the actual EMU crisis period, the ECB's quantitative easing policies focused on expanding its balance sheet rather than reallocating it (Jäger and Grigoriadis 2017), and targeted both financial distress and sovereign issuances. Foremost amongst these policies was the Covered Bond Purchase Programme (CBPP), going forward originally in two phases from July 2009-June 2010 to November 2011-October 2012, which spent EUR 100 billion on purchasing covered bonds in order to ensure bank liquidity (Ibid.). Concurrently with the CBPP was the Securities Markets Programme (SMP), where Member State sovereign bonds were purchased to provide liquidity in 'dysfunctional' market segments. (Haitsma, Unalmis, and de Haan 2016). The SMP lasted in its first phase from May 2010 to March 2011, resuming again in August 2011 and lasting through February 2012, with a total of EUR 240 billion spent on distressed sovereign debt (Gibson, Hall, and Tavlas 2016). The SMP was then superseded by the Outright Monetary Transactions (OMT) program, the outcome of Draghi's famous 'whatever it takes' speech, where the ECB would have no limits on its sovereign bond-buying program. The ECB recently noted that the OMT 'served as a powerful circuit breaker of the ongoing downward spiral' (Praet 2018).

- Expanded Asset Purchases: Finally, the most expansive of the ECB's interventions into the market was the Expanded Asset Purchase Programme (EAPP), a multi-faceted program which included the corporate sector purchase programme (CSPP), the public sector purchase programme (PSPP), the asset-backed securities purchase programme (ABSPP), and a third CBPP program (CBPP3) initiated in 2015. According to the ECB, across all of these programs, monthly purchases were conducted at an average pace of EUR60 billion from March 2015 until March 2016, EUR80 billion from April 2016 until March 2017, EUR60 billion from April 2017 to December 2017, EUR30 billion from January 2018 to September 2018, and EUR15 billion from September 2018 to its wind-down in December 2018 (as of this writing, the ECB is continuing to reinvest the principal from its already-purchased securities, however). The vast majority of holdings under the EAPP were once again sovereign debt instruments, as the PSPP had holdings over EUR 2.5 billion by August 2018.

\subsection{The (Not Quite-) Aftermath}

Given this huge influx of liquidity into the markets, coupled with the massive intervention of the ECB into both financial and sovereign debt markets, the largest question which must confront economists is whether or not the actions of the ECB actually helped to overcome the crisis. Did this unconventional policy package, occurring over such a long period of time, mitigate the effects of the crisis or did it prolong its effects while merely treating the symptoms?

As of this writing, there is a growing body of evidence that the ECB's measures were effective according to a narrow set of metrics. Perhaps not surprisingly, research conducted by researchers at the ECB have found positive effects across all unconventional programs. For example, an early paper by Giannone et al. (2012) showed how crisis measures by the ECB had a positive influence on the interbank market. Altavilla, Giannone, and Lenza (2016), concentrating solely on the OMT program, show that it had a positive effect on the hardest-hit countries of the euro area, and thus was a successfully targeted measure. Fratzscher, Duca, and Straub (2016), examining the panoply of measures introduced from 2007 to 2012, discovered that the ECB's responses not only were good for the euro area, but helped reduced risk across the whole G-20. Turning to the EAPP, Georgiadis and Gräb (2016) found that it boosted investor confidence in the euro area and actually caused a 're-balancing' of capital flows from emerging markets back into developed ones. Similarly, Eser and Schwaab (2016) show that asset purchases improved liquidity conditions in the euro area while decreasing default risk (interestingly, a goal that low interest rates did not fulfil).

Outside of the ECB headquarters, researchers have found similar effects: both Falagiarda and Reitz (2015) and Krishnamurthy, Nagel, and Vissing-Jorgensen (2017) show that the ECB's interventions lowered risk premia on distressed sovereigns in the euro area, while boosting equity prices as a beneficial macro-spillover. Szczerbowicz (2015) argues that asset purchases lowered the refinancing costs of banks and governments while 
also showing positive spillover effects across the euro area economy. And several other papers (Saka, Fuertes, and Kalotychou 2015; Ghysels et al. 2016, and to take two examples) reinforce the ECB's own research in showing that the unconventional policies of the Bank had salutary effects. In sum, it appears that there is a consensus that the ECB's policies were effective in the specific areas which were targeted.

Perhaps more of concern to ECB policymakers, especially from 2014 onward, was the threat of disinflation turning into deflation, a point stressed in speech after speech. After 10 years of unconventional monetary policy, it appears that this too was a success, as inflation expectations are finally rising in the euro area again (Figure 3). Although expectations are still below where they were at the outset of the EMU crisis - and, crucially, are still below the ECB target rate of 2 percent and trending downward - they are far above where they were at the beginning of 2017. This is in line with the actual inflation data from the ECB, which shows that the 2 percent target was reached in June 2018 and hit a high of 2.3 percent in October 2018 but has since come down to 1.1 percent in July 2019. Indeed, the rise in prices in 2018 appeared to be mainly attributable to energy prices and, to a lesser extent, food, alcohol and tobacco, meaning that services and industrial goods were relatively flatter... and have remained that way.

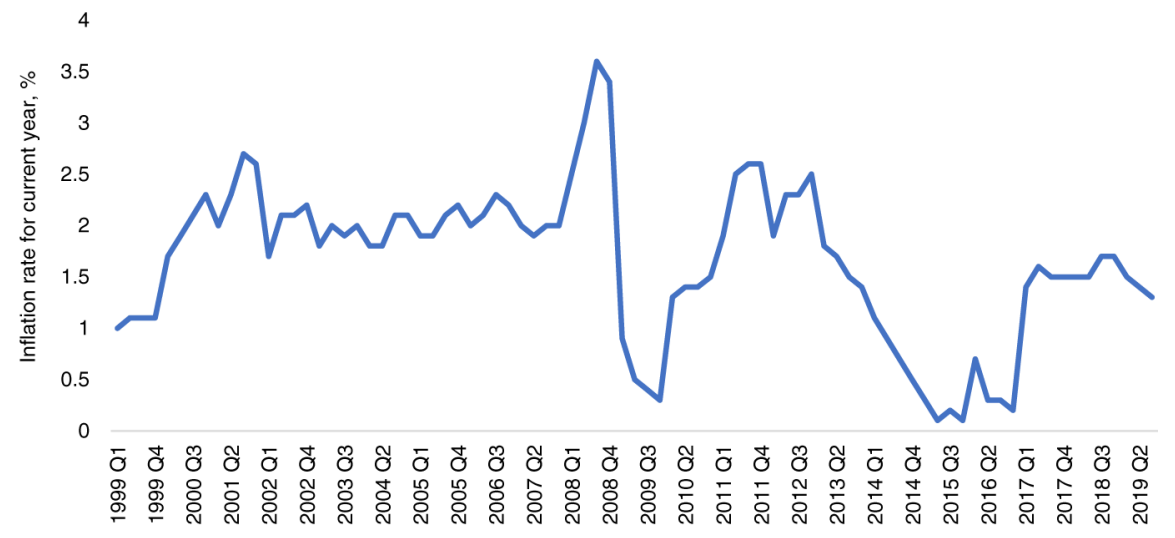

Figure 3: Inflation Expectations for the Current Year in the Euro Area, 1999-2019.

Source: ECB Survey of Professional Forecasters.

These results gave a glimmer of hope to ECB policymakers and indeed leaders and governments in each of the euro area countries, as it appeared that the bogeyman of deflation, if not defeated, was somewhat contained (of course, the reality of deflation actually being bad for the euro area is a debate for another paper). However, given the precarious state of Italy's finances and the fact that there is once again talk about the possibility of a massive euro area crisis, it can be argued that these positive effects of the ECB's unconventional policies, shown in the literature noted above, were merely temporary. Indeed, the current state of sluggish growth in the euro area, coupled with gathering clouds over sovereign debt burdens and persistent financial market distortions (Cecchetti, Griffoli, and Narita 2017; Cesa-Bianchi and Rebucci 2017), suggests that the unconventional monetary policy of the ECB did not actually address the root causes of the EMU crisis; as such, the crisis never really ended, it just went on hold (although in the case of the financial market, as the above-referenced papers show, monetary policies may have exacerbated instability). In fact, it is more accurate to note that the ECB's policies could never have addressed the root causes of the crisis, as monetary policy is a poor instrument to tackle structural issues (which appear to have not been addressed during the time of unconventional monetary policy). This reality is examined in the next two sections, as we explore a) how the ECB is institutionally constrained in what it can do, even with an increase in its powers, and b) how increasing the ECB's powers may make things in the euro area demonstrably worse, in terms of distortions and complex (unforeseen) follow-on effects.

\section{The ECB, an Institution like No Other (but still an Institution)}

Literally thousands of pages have been devoted to the structural issues plaguing the euro area, mainly in relation to its status as a (non-) optimal currency area, the difficulties in managing a single policy across so many diverse countries, and the need for additional integration initiatives to make the job of monetary management easier for the ECB (Talani (2016) is an excellent overview of these issues). However, comparatively less work has been done on the ECB as an institution, with research that has been produced preferring to focus on either the ECB's 'independence' (Lombardi and Moschella 2016), on its modalities of communication (Amaya and Filbien 2015; Picault and Renault 2017), or on clashes between its mandates of overseeing the EMU and in guaranteeing financial stability (Issing 2017), with additional papers coming at the ECB from a non-economic standpoint but 
also focusing on independence and the EU system as a whole (Schmidt and Thatcher 2014; Giannone 2015). Without an understanding of the institutional imperatives of the ECB, it is impossible to understand the possible effects of any further additional mandates it receives going forward. That is the purpose of this section.

\subsection{One Institution Amongst Many}

Lost in the shuffle of research around the ECB as a powerful institution, able to command billions of euros and reduce sovereign risk ratings via its programs, is the reality that the ECB is an institution which is embedded in a web of economic and political institutions across the European Union. While it stands as primus inter pares for monetary policy, overseeing the 19 Member State central banks, having competency for establishing euro area interest rates, and directing purchase programs, the ECB is in reality just one institution in the implementation of monetary policy. Indeed, it can be argued (as I will in Section 4) that the ECB may be the institution which sets monetary policy, but implementation of it is left to others. More important for this section is understanding that even the setting of monetary policy is determined by the political environment in which the ECB works, making its policy independence much smaller than the ECB (or other commentators) believes it to be. Indeed, the ECB is often portrayed as the police, setting the rules for economic policy, when in reality it is closer to the fire department, cleaning up after messes that others have made.

In the first instance, the ECB, as an interest group comprised of various Member State governors and public figures, is undeniably a player in the politics of EMU as well as in the implementation of its policy (Torres 2013), a realm where the ECB may be seen as more of a soldier than a leader. Realistically, this is not a trait unique to the ECB; as Hartwell (2018a) shows, all central banks remain highly dependent upon the institutional environment in which they are birthed and where they operate. Indeed, the whole idea animating 'central bank independence' is that the time inconsistency problem of Kydland and Prescott (1977) can be mitigated by removing political pressures from the central bank, but as Hartwell (2018a) describes, these pressures can actually never be removed. Politicians may continually have opinions on what monetary policy should be (and express this publicly), and central bank governors are chosen via a political process (and, in the case of the euro area, via an inter-state negotiation as well). And central bankers are never entirely secure in their jobs, for, as Hayo and Voigt (2008), 752 note, 'if government has the capacity to create a formally independent central bank, it might also be strong enough to overrule its decisions, simply ignore them, or abolish the independent central bank again'.

Most importantly, politicians, via their fiscal policies, create conditions in which the central bank must act and react. To return to the overwhelming literature on the misalignment between fiscal policy and monetary policies amongst the 19 euro area countries (Alessandrini and Fratianni 2016), it is clear that the ECB's policy independence is severely undercut by the independent fiscal policies pursued by Member States. This is not an argument for fiscal union or even more closely aligned policies amongst members, but merely an observation that, as currently constructed, the euro area forces the ECB to accommodate 19 separate fiscal policies that it has no control over. This problem is very distinct from the operations of the US Federal Reserve, which has its own form of decentralization in its constituent banks spread out over 12 districts but only one federal government to deal with. ${ }^{2}$

A severe misalignment of incentives at the euro area level has thus resulted, manifested in either domestic policies that had no consideration of broader, euro area effects, or from domestic policies that were predicated precisely on the ECB providing a bailout for profligate or inefficient policy; indeed, Cancelo, Varela, and Sánchez-Santos (2011) show that members of the ECB Governing Council bring their own national baggage to monetary policies, and Hayo and Méon (2013) detail how this reality leads to ECB members setting monetary policy as a conglomeration of national needs rather than focusing on a euro area-only approach. And while the exact cause of the EMU crisis is in dispute, there is no doubt that the individual members of the ECB and their sovereign debt issues played a major role in starting the crisis. ${ }^{3}$

With 19 different fiscal policies and misaligned incentives, and ECB decision-making predicated on forging a consensus constructed from individual country preferences, it is thus plain to see that the policy independence of the ECB - especially a mandate to focus on price stability - was severely undercut, forcing the ECB to come to the rescue of government after government. Indeed, looking at the ECB's response to the EMU crisis, and as noted in the previous section, the largest portion of unconventional monetary policy was dedicated solely to purchasing sovereign bonds, i.e. providing funding for governments and reducing sovereign risks. Thus, not only did sovereign debt possibly cause the crisis, but it necessitated a massive response from the ECB to attempt to clean up the results of these specifically fiscal policies. One can argue that the days of monetizing government debt are over because of central bank independence, but it is hard to argue that such a scenario did not occur in the ECB's monetary response to the dual crises.

A final point about the ECB's lack of policy independence is also directly related to the second half of the $E C B$ 's unconventional monetary policies, which was directed at keeping financial markets afloat. Beyond the 
political pressures that central banks face, and returning to the idea in Issing (2017), that the ECB's dual mandate for EMU and financial sector stability can be undercutting its independence, is the fact that all central banks tend to be influenced by one particular domestic interest group, namely the financial sector (Wray 2007). Going as far back as Roberts (1911), we can see that central banks are perceived by the financial sector as a subsidy for these institutions, helping them to recoup losses incurred as a result of competition and the market. Indeed, the misalignment of incentives between the financial sector and the ECB is simply the flip side of the misalignment between sovereign Member States and the ECB, as banks have little incentive to worry about systemic stability (especially at the expense of its own bottom line). With the twin crises of 2007-2008 and 2009 and still ongoing, the ECB was forced into generating unconventional ways of salvaging the financial sector in addition to keeping the sovereign debt market afloat.

\subsection{More Instruments, Less Power?}

In neither instance, either purchasing sovereign bonds or injecting liquidity into the bond and interbank markets, did the ECB have the operational independence that it is claimed to have. Seen from this perspective, even the creation of more instruments and further unconventional monetary policy may thus not be effective in ensuring the efficacy of the euro or helping to preserve monetary stability.

The simple reason for this reality is that the underlying issues behind the EMU crisis persist: in the shortrun, as research noted above from the ECB and others has shown, programs such as EAPP did indeed ease government funding pressures and helped to reduce sovereign risk, but the long-term misalignments still remain (as witnessed by the latest hand-wringing over Italy). Even expanding the ECB's arsenal of weaponry and including new and even more exotic ways of injecting liquidity will be for naught if all these instruments do are enable governments to pursue inadequate fiscal policies. Put another way, the story of the past decade has been one of fiscal policy shenanigans attempting to create a policy space separate from, and in many ways in opposition to, the ECB's policies. As noted in the central bank independence literature, the preferences of a society for particular economic policies are endogenous, and institutional arrangements often lag these preferences rather than transform them (Mas 1995). With no fiscal union in place (and little hope of creating one) and a Maastricht treaty hollowed from neglect out from the top, it is highly likely that additional instruments (such as the completely unbelievable helicopter money or deep negative rates) will just focus Member State energies towards a greater acceptance of monetary solutions for fiscal problems.

From the financial sector side as well, allowing the ECB to engineer new and unconventional instruments even larger in size than those deployed during the most recent crisis can only create a larger moral hazard. In this sense, and going back to Roberts (1911), bankers will be attempting to recoup via government what they would lose to the market, privatising profit while socialising risk. More succinctly, expanding the ECB's arsenal to provide for the financial sector creates a soft budget constraint: while the concept was originally used by Kornai (1986) in reference to state-owned enterprises under communism, it applies in this case as well, as banks can run risks and incur losses with little fear of market discipline or reprisals. Of course, specific banks may close down or be taken over, but the risk of any one bank being the one which is made the example is small (and staff may find another position in the financial sector anyway). By promising to do 'whatever it takes' to save the financial sector, the fundamental issues of risk pricing and legislative fiat (i.e. directed lending) are glossed over.

Given these structural issues, the issue may be less about a set of new tools available for the next crisis and more about how to dismantle the tools invented for this current one. The reason for this should become clear in the next section.

\section{The Complexity of Monetary Policy}

Given these institutional constraints surrounding the ECB, it is highly unlikely that additional 'unconventional' tools will be able to bring the euro area economy to a period of stability - this, after all, is supposed to be the goal of the ECB, fostering an environment of price stability in which economic growth can occur. Indeed, it is too easy to forget that the ECB's mandate, first and foremost, is price stability, with secondary goals such as employment or financial stability desirable insofar as they do not contradict the first. But with the move towards unconventional monetary policy, a choice has been forced upon the ECB by its Member States to also consider fiscal health as a crucial and equal goal. And with fiscal issues continually reining in the ECB's independence to pursue price stability, it is doubtful that bigger and more bizarre monetary instruments can introduce this stability to the euro area when politics and domestic government will not. 
One may argue (as others have) that the ECB should be less about a single-minded pursuit of price stability and be allowed to focus on financial stability and/or growth or fiscal health as a complement (Fratzscher 2016). Seen in this light, the creation of tools such as the EAPP, and especially the accommodation of looser fiscal policy, is one of the rightful objectives of the ECB and thus any impact it has on independence is less important in the longer-term (Weber and Forschner 2014). Additionally, others have argued that, by circumscribing the ECB more and by making it a tool of economic policy under the service of the Member States, expanding the ECB's mandate to officially encompass many of the areas it already targeted during the crisis, this would help to bring more democracy to EU economic policy-making (Smith and Weeks 2018).

However, this ex post justification for unconventional monetary policy and, more worrying, the emphasis on expanding instruments via helicopter money, deep negative interest rates, and the like is that the deleterious consequences of such policies have not been fully explored. This paper does not, unfortunately, explore these possible consequences in depth, but merely suggests them here based on other research, in a way to stimulate discussion and further work in this important area. For example, in pursuit of broader economic 'stability' via monetary means, additional unforeseen and negative consequences for the economy and in particular for institutional development may be unleashed. This is a separate question from if unconventional monetary policy actually 'worked': as I noted above, the research on the effects of the ECB's monetary policy during the crisis are concentrated on a narrow set of economic metrics, but after a decade of unconventional monetary policy, including massive injections of liquidity, zero interest rates, and other instruments growth has only tentatively returned to the euro area. No, the question is, what are the longer-term negative effects of unconventional monetary policy, not only for countries outside the bloc (Bluwstein and Canova 2016) but for those inside of it?

In order to explore this question, this section draws on the growing literature in economics which attempts to apply insights from the natural sciences to economic phenomena, with the most promising avenue related to 'complexity economics'. Put simply, complexity theory posits that dynamical systems have several traits, including sensitivity to initial conditions, non-linearity, susceptibility to external forces, differences between local and global information, and multiple equilibria depending upon the ongoing adaptation of actors in the system. These tenets have been applied to monetary policy more broadly, with complexity able to show the difficulties in running such an interventionist policy. The areas where complexity come most into play are monetary behaviour, and the institutional effects of money.

\subsection{Complex Money...}

Money itself behaves in a complex and non-ergodic manner, a trait which makes targeting economic aggregates involving money very difficult to do successfully. For example, Barnett and Chen (1988) studied monetary aggregates in the United States and found that they contained clear evidence of mathematical chaos. Follow-on research such as DeCoster and Mitchell (1991) and Serletis (1995) confirmed the presence of chaotic behaviour in both monetary aggregates and the velocity of money, while DeCoster and Mitchell (1992) showed that this behaviour in money led directly to an increase in chaotic behaviour in most nominal macroeconomic aggregates.

Given the chaotic nature of money, further research has shown the difficulty facing monetary authorities, as papers such as Soliman (1996), 148 make the point that 'small disturbances [in monetary policy] may result in a qualitative change in the response of the [monetary] system', with 'the long-term behaviour of the system... dependent upon the initial conditions'. Perhaps the main reason why monetary policy inherently displays chaotic attributes was noted by Friedman $(1953,1961)$ : given incomplete information on the part of the monetary policymaker, coupled with a variable lag before monetary policy comes to fruition and its effects are seen, an economy can move substantially from the circumstances at time $t$, when the policy was enacted, to time $t+n$, when the policy takes effect. This can be seen in Solomon and Solomon (1991), who show in a nonlinear model of money in the United States that this lag introduces instability and chaos into money supply aggregates. When considering that monetary policy itself makes money more chaotic, it is thus no surprise that an extension of this reality is that monetary policy at time $t+n+1$ is even more difficult to control. As Ramsey $(1990,81)$ brilliantly phrased it, 'we have now come to the realization that models of money demand... provide reasonable forecasts only in those cases where the models are not really needed'.

A key source of non-linearity in the execution of monetary policy is expectations, a point enshrined in the Lucas (1976) Critique: namely, that monetary policy itself shifts the expectations of participants in the economy, meaning that a policy undertaken at time $t$ and based on the conditions prevailing at that point would be acted upon and probably expected by participants, meaning that its effects at time $t+n$ would be different than anticipated. Indeed, Lucas noted that predicting the effect of a policy change would not be valid if the policy change alters expectations in a way that changes the fundamental relationships between variables.

While Lucas was speaking narrowly of econometric policy evaluation and modelling, his point holds true in terms of monetary policy itself, which bases its current instruments based on projections of how agents will act in the future. Indeed, even incorporating expectations in a monetary model may not lead to optimal outcomes 
if expectations follow a chaotic course, meaning that policymakers would have to try more and more esoteric models and more and more erratic instruments. As Taylor and Williams (2010), 845 note, the problem with 'optimal policies is that they tend to be very complicated and potentially difficult to communicate to the public, relative to simple rules. In an environment where the pubic lacks a perfect understanding of the policy strategy, this complexity may make it harder for private agents to learn, creating confusion and expectational errors.' This reality was confirmed in recent work by Kawai, Lang, and Li (2018), who show that complex policies tend to beget complex policies.

The issue at play here is that monetary policymakers are not actually making the economy more stable but are creating chaos via their effects on expectations. In fact, the complexity of monetary policy means that not only are expectations changed throughout an economy due to monetary policy at time $t$, the responses within the system are not consistent even if the same action is repeated and announced well in advance (i.e. using preannounced rules)! As Mohseni, Zhang, and Cao (2015) show, even the use of various standard monetary policy rules can induce complex and non-linear behaviour into an economy, with the forward-looking Taylor rule incorporating rational expectations the biggest culprit in creating non-linear behaviour. By unnecessarily increasing the complexity of monetary policy and attempting to anticipate shifting expectations, policymakers continue to alter the fundamental variables in the economy but without improving the relationship amongst these variables.

The parallels to the ECB's policies over the past decade should be apparent, and more and more exotic instruments were used in an attempt to shift expectations. And yet, expectations have become less forwardlooking and based on a shorter time span, as economic policy uncertainty has spiked, and ECB meetings have become more important for what their decisions will be. Introducing 'innovations' such as helicopter money would only increase the complexity of monetary policies, making expectations even more difficult to manage... if such a thing is even possible.

\section{$4.2 \quad$...Complex Effects}

Finally, assuming that the ECB is able to overcome the hurdles of institutional constraints, endogeneity of expectations, and the inherent complexity of money by utilising ever more unconventional instruments, there are additional effects to consider which have only begun to be explored in economic research (Hartwell 2019). The experience of the past 10 years has shown that unconventional monetary policy has taken a circuitous route towards economic recovery while not addressing the underlying causes of the euro area crisis, which are themselves institutional. Thus far unexamined has been the effect that unconventional monetary policy has had on the other institutional players in the European economy. Explained another way, if the ECB is but one institution amongst many and is influenced by these other institutions (as shown in Section 3), how does the regarding the euro area and were not addressed during the period of unconventional monetary policy, is it possible these policies had institutional effects elsewhere?

New advances in the study of the effects of monetary policy have attempted to isolate the effect that monetary policy and monetary policy institutions have on the political and economic institutions with which they interact. Complexity economics can also help to understand these effects, for institutions are also complex creatures who exist in an institutional ecosystem and bump up against, overlap with, and are influenced by other institutions. Given their path dependence and sensitivity to external conditions, institutional development can be changed substantially by a nudge from external macroeconomic policies. Paramount amongst these policies would be monetary policy, which has the ability to not only change monetary aggregates but to influence politics in a country. The consequences of monetary profligacy would thus be as unforeseen in the medium-term as they are predictable in the short-term (Durlauf 2012), with the ability to threaten fragile governance systems (Duit and Galaz 2008), reshape political institutional structures, and reorder existing economic relationships.

Koyama and Johnson (2015) lay out the mechanisms how lack of monetary stability can impact a specific institutional arrangement, that of political development, noting that monetary profligacy can lead directly to a negative impact on the rule of law; they posit that unstable monetary policy, by disrupting the price system, creates incentives to engage in non-market (i.e. political) transactions rather than building market-friendly institutions. In their examination, they provide evidence that high inflation is associated with bad economic policies more generally (an artificially-generated crisis begetting even worse solutions), and that high inflation and diminished rule of law go hand-in-hand. Moreover, out-of-control monetary policy tends to increase state intervention more generally, as the forces unleashed by inflation lead polities to favour 'strong' parties which can deliver 'stability'.

Further evidence for this hypothesis has been shown by Hartwell (2018b), who examines interwar Poland and shows how profligate monetary policy led directly to (i.e. had a causal link with) erosion of the rule of law and degradation of political institutions. By abandoning monetary rectitude in pursuit of fiscal goals, the 
new Republic negatively impacted the country's fledgling political institutions. Similar work in this vein has been done on the interwar period for Germany, with work such as Hill, Butler, and Lorenzen (1977) and Van Riel and Schram (1993) pointing out how hyperinflation weakened the Weimar Republic. In each of these cases, after controlling for several other possible variables, the negative link between unstable monetary policy and the rule of law was established.

While these historical episodes may appear to be of little relevance for the Europe of today, given the theoretical linkages between monetary policy and degradation of the rule of law, it is perhaps interesting to note that there may also be a connection between the loose monetary policies of the past decade and the ascendance of populism throughout Europe over that same time frame. It would be difficult, in such a short span of time (and given the limitations of our modelling capabilities) to prove such a hypothesis conclusively, and I make no claim here that this is definitively the case. From a purely practical standpoint, the ECB's actions cannot necessarily explain populist electoral gains in countries who are not actually on the euro (such as the Czech Republic and Poland predominantly), nor can it explain the Brexit referendum and the UK's decision to leave the EU.

However, this does not mean that there is no evidence nor theoretical channels linking quantitative easing to the unfortunate degradation of the rule of law in the Europe of today. Much of the anti-globalization backlash occurring in Europe's periphery (and I include the UK in that group) has a strong anti-euro, anti-EU component, and peaked as a direct result of the euro area crisis; as Bluwstein and Canova (2016) showed, unconventional monetary policy hit countries with advanced financial systems linked to the euro area but not explicitly part of the euro the hardest, making the ECB a natural target for populist ire. At the same time, unconventional monetary policy may also be linked to the rise of populist parties more generally within the euro area, as doubling down on European integration brought hardship (although not 'austerity') for little apparent gain. As noted in Domanski, Scatigna, and Zabai (2016) and Mumtaz and Theophilopoulou (2017), and others, income and wealth inequality increased dramatically after the global financial crisis, with the inflation of equity values and direct bailout of financial sector stakeholders benefiting one segment of society and the zeroto-negative return on short-term financial holdings disadvantaging others (Montecino and Epstein 2015). Such imbalances necessarily translated into electoral backlashes (International Monetary Fund 2016; Wilkin 2017), a point also made by Guriev (2018) in the context of perception of "fairness." Put simply, rising inequality, created by unconventional monetary policy, was one of the causes for the current populist wave. And to continue with the mechanisms elucidated in Koyama and Johnson (2015), if even a massive injection of liquidity did not bring stability and the euro area remains on the brink, the instability of the euro area will entice the median voter to vote for parties which not only focus on fairness but that promise a radical change. Railing against the (hardly) 'neoliberal' policies of the ECB makes a handy cudgel for populist parties.

From 2015 to 2018, populist parties across the euro area made sizeable gains precisely on such a platform, not explicitly linked to monetary policy but more based on a general anti-EU, anti-elite sentiment and a desire to radically change course from the instability of the previous decade. The ascendance of the Italian Five-Star Movement, the Freedom Party in Austria, Syriza in Greece, Alternative for Germany (AfD), and other populist movements has led to entry into or control of government; even where populists have not been in charge, they have had a surge in popularity, holding firm at between nearly 13 percentage of the vote (Germany, France, and the Netherlands) up to 18 percentage in Finland. And although it is too soon to prove causality - and again, this is part of a larger research program in political economy beyond the scope of this paper - one could plausibly trace the connections between the upsurge in populism and massive injections of liquidity by the ECB via the EAPP, done precisely to preserve fiscal policies which were unsustainable. In short, while there may be massive issues of endogeneity and reverse causality (did the ECB act in order to stave off populism?), the Koyama and Johnson thesis appears to have some credibility here: monetary profligacy correlates with lower rule of law and begets additional bad (fiscal) policies.

More importantly from a complexity economics standpoint, the medium-term effects of the ECB's actions cannot be foreseen. In examples from history, such as Poland and Germany, the weakening of internal institutions effected by monetary policy led to external conflict and destruction; in other cases, such as Hungary's hyperinflation of 1946, monetary instability led not only to takeover by an external aggressor, but also development of political institutions based on a more populist worldview (Hartwell 2019). The worry is that additional monetary interventions by the ECB would change the path of the euro area's institutional development in negative ways which cannot be predicted. 


\section{Conclusions}

This brief paper has taken an unorthodox look at the ECB's use of unconventional monetary policy over the past decade and assessed whether or not new and exotic instruments should be utilised to overcome the next crisis.

The answer, based on tenets of complexity theory and the reality of the past decade, is that they should not, and indeed an ending of all unconventional monetary policies should happen as soon as possible. Unconventional monetary policy has not delivered stability to the euro area, as the ECB is institutionally constrained to deliver the stability which is necessary. Moreover, the ECB has actually increased the complexity and chaos in the monetary system via its unconventional policies, leaving agents in the economy unmoored with regard to their expectations. Finally, the deleterious consequences of unconventional monetary policy have been littleexplored, but the author's opinion is that the links between European monetary policymaking have contributed to the rise of populism on the continent (including adding fuel to the fire of Brexit, anti-globalization, and antiimmigrant sentiment Europe-wide); however, these links need to be more explicitly researched before we can conclusively say that unconventional monetary policy was a definitive cause of the current populist wave.

Given these realities, the question should not be 'is the ECB equipped to deal with the next crisis?' but 'how can the ECB unwind its damage from the last one?' By resorting to the insights of complexity economics, and examining the EMU crisis with an institutional lens, it is clear that the answer is to return to conventional monetary policy as soon as possible. Refocusing on the ECB's mandate of price stability will keep monetary policy anchored on monetary issues, which is crucial: monetary policy is no solution for structural issues, and so long as the misalignments within the euro area are enabled by monetary policy, the structural changes needed will never be enacted.

\section{Funding}

European Parliament, funder id: http://dx.doi.org/10.13039/501100000784, Grant Number: $\mathrm{IP} / \mathrm{A} / \mathrm{ECON} / 2018-18$.

\section{Notes}

1 As will be shown below, the special nature of the ECB, overseeing 19 independent fiscal policies, also made targeting root causes incredibly difficult.

While the United States of America is split up into 50 states, each with their own fiscal policies, the federal government has enormous power in fiscal transfers and budgetary setting so that the Federal Reserve System is set up to exclusively target national-level aggregates. While state-level budgetary problems could impact on the federal budget, these effects would be removed from decision-making at the Fed.

3 The research cited above perhaps proves that if addressing sovereign debt woes created the largest amount of macroeconomic spillovers, maybe sovereign debt was the key issue all along.

\section{References}

Alessandrini, P., and M. Fratianni. 2016. “In the Absence of Fiscal Union, the Eurozone Needs a more Flexible Monetary Policy." PSL Quarterly Review 68 (275): 279-296.

Altavilla, C., D. Giannone, and M. Lenza. 2016. "The Financial and Macroeconomic Effects of the OMT Announcements." International Journal ofCentral Banking 12 (3): 29-57.

Amaya, D., and J. Y. Filbien. 2015. “The Similarity of ECB's Communication." Finance Research Letters 13: 234-242.

Baldwin, R., and F. Giavazzi. 2015. The Eurozone Crisis: A Consensus View of the Causes and a Few Possible Solutions. VoxEU.org e-book, September, available at https://voxeu.org/content/eurozone-crisis-consensus-view-causes-and-few-possible-solutions.

Barnett, W. A., and P. Chen. 1988. "The Aggregation-Theoretic Monetary Aggregates Are Chaotic and Have Strange Attractors: An Econometric Application of Mathematical Chaos." In Dynamic Econometric Modelling, edited by W. Barnett, E. Berndt, and H. White, 199-246. Cambridge: Cambridge University Press.

Bluwstein, K., and F. Canova. 2016. “Beggar-Thy-Neighbor? The International Effects of ECB Unconventional Monetary Policy Measures." International Journal of Central Banking 12 (3): 69-120.

Cancelo, J. R., D. Varela, and J. M. Sánchez-Santos. 2011. “Interest Rate Setting at the ECB: Individual Preferences and Collective Decision Making." Journal of Policy Modeling 33 (6): 804-820.

Cecchetti, S., T. M. Griffoli, and M. Narita. 2017. Does Prolonged Monetary Policy Easing Increase Financial Vulnerability? (No. 17/65). International Monetary Fund. 
Cesa-Bianchi, A., and A. Rebucci. 2017. “Does Easing Monetary Policy Increase Financial Instability?” Journal of Financial Stability $30: 111-125$. DeCoster, G. P., and D. W. Mitchell. 1991. “Nonlinear Monetary Dynamics." Journal of Business \& Economic Statistics 9 (4): $455-461$.

DeCoster, G. P., and D. W. Mitchell. 1992. “Dynamic Implications of Chaotic Monetary Policy.” Journal of Macroeconomics 14 (2): $267-287$.

Domanski, D., M. Scatigna, and A. Zabai. 2016. “Wealth Inequality and Monetary Policy.” BIS Quarterly Review, March, 45-64. https://www.bis.org/publ/qtrpdf/r_qt1603.pdf.

Duit, A., and V. Galaz. 2008. “Covernance and Complexity - Emerging Issues for Covernance Theory.” Covernance 21 (3): 311-335.

Durlauf, S. N. 2012. “Complexity, Economics, and Public Policy." Politics, Philosophy \& Economics 11 (1): 45-75.

Eser, F., and B. Schwaab. 2016. "Evaluating the Impact of Unconventional Monetary Policy Measures: Empirical Evidence from the ECB's Securities Markets Programme." Journal of Financial Economics 119 (1): 147-167.

Falagiarda, M., and S. Reitz. 2015. “Announcements of ECB Unconventional Programs: Implications for the Sovereign Spreads of Stressed Euro Area Countries." Journal of International Money and Finance 53: 276-295.

Fratzscher, M. 2016. “Rules Versus Human Beings, and the Mandate of the ECB.” CESifo Economic Studies 62 (1): 68-87.

Fratzscher, M., M. L. Duca, and R. Straub. 2016. “ECB Unconventional Monetary Policy: Market Impact and International Spillovers." IMF Economic Review 64 (1): 36-74.

Friedman, M. 1953. “The Effects of a Full-Employment Policy on Economic Stability: A Formal Analysis." In Essays in Positive Economics, 117-132. Chicago: University of Chicago Press.

Friedman, M. 1961. "The lag in effect of monetary policy." Journal of Political Economy 69 (5): 447-66.

Georgiadis, C., and J. Gräb. 2016. "Clobal Financial Market Impact of the Announcement of the ECB's Asset Purchase Programme." Journal of Financial Stability 26: 257-265.

Chysels, E., J. Idier, S. Manganelli, and O. Vergote. 2016. "A High-Frequency Assessment of the ECB Securities Markets Programme." Journal of the European Economic Association 15 (1): 218-243.

Ciannone, D. 2015. "Suspending Democracy? The Covernance of the EU's Political and Economic Crisis as a Process of Neoliberal Restructuring." In The European Union in Crisis, edited by K. N. Demetriou, 101-119. Berlin: Springer.

Giannone, D., M. Lenza, H. Pill, and L. Reichlin. 2012. “The ECB and the Interbank Market.” The Economic Journal 122 (564): F467-F486.

Gibson, H. D., S. G. Hall, and G. S. Tavlas. 2016. “The Effectiveness of the ECB's Asset Purchase Programs of 2009 to 2012." Journal of Macroeconomics 47: 45-57.

Guriev, S. 2018. “Economic Drivers of Populism.” American Economic Review: Papers and Proceedings 108: 200-203.

Haitsma, R., D. Unalmis, and J. de Haan. 2016. "The Impact of the ECB's Conventional and Unconventional Monetary Policies on Stock Markets." Journal of Macroeconomics 48: 101-116.

Hartwell, C. A. 2018a. "On the Impossibility of Central Bank Independence: Four Decades of Time-(and Intellectual) Inconsistency." Cambridge Journal of Economics 43 (1): 61-84.

Hartwell, C. A. 2018b. "The 'Hierarchy of Institutions' Reconsidered: Monetary Policy and its Effect on the Rule of Law in Interwar Poland." Explorations in Economic History 68: 37-70.

Hartwell, C. A. 2019. "Short Waves in Hungary, 1923 and 1946: Persistence, Chaos, and (Lack of) Control." Journal of Economic Behavior \& Organization 163: 532-550.

Hayo, B., and S. Voigt. 2008. "Inflation, Central Bank Independence, and the Legal System." Journal of Institutional and Theoretical Economics JITE 164 (4): 751-777.

Hayo, B., and P. G. Méon. 2013. “Behind Closed Doors: Revealing the ECB's Decision Rule." Journal of International Money and Finance 37: 135160.

Hill, L. E., C. E. Butler, and S. A. Lorenzen. 1977. "Inflation and the Destruction of Democracy: The Case of the Weimar Republic." Journal of Economic Issues 11 (2): 299-313.

International Monetary Fund. 2016. Clobal Financial Stability Report- Fostering Stability in a Low-Growth, Low-Rate Era. Washington, DC: IMF Press.

Issing, O. 2017. “Central Banks - are their Reputations and Independence under Threat from Overburdening?" International Finance 20 (1): 92-99.

Jäger, J., and T. Crigoriadis. 2017. "The Effectiveness of the ECB's Unconventional Monetary Policy: Comparative Evidence from Crisis and Non-Crisis Euro-Area Countries." Journal of International Money and Finance 78: 21-43.

Kawai, K., R. Lang, and H. Li. 2018. “Political Kludges.” American Economic Journal: Microeconomics 10 (4): 131-158.

Kornai, J. 1986. “The Soft Budget Constraint." Kyklos 39 (1): 3-30.

Koyama, M., and B. Johnson. 2015. "Monetary Stability and the Rule of Law." Journal of Financial Stability 17: 46-58.

Krishnamurthy, A., S. Nagel, and A. Vissing-Jorgensen. 2017. "ECB Policies Involving Government Bond Purchases: Impact and Channels." Review of Finance 22 (1): 1-44.

Kydland, F. E., and E. C. Prescott. 1977. “Rules Rather than Discretion: The Inconsistency of Optimal Plans." Journal of Political Economy 85 (3): 473-491.

Lenza, M., H. Pill, and L. Reichlin. 2010. “Monetary Policy in Exceptional Times.” Economic Policy 25 (62): 295-339.

Lombardi, D., and M. Moschella. 2016. "The Government Bond Buying Programmes of the European Central Bank: An Analysis of their Policy Settings." Journal of European Public Policy 23 (6): 851-870.

Lucas ]r, R. 1976. “Econometric Policy Evaluation: A Critique." Carnegie-Rochester Conference Series on Public Policy 1 (1): 19-46.

Martin, P., and T. Philippon. 2017. "Inspecting the Mechanism: Leverage and the Great Recession in the Eurozone." American Economic Review 107 (7): 1904-1937.

Mas, I. 1995. “Central Bank Independence: A Critical View from a Developing Country Perspective.” World Development 23 (10): 1639-1652.

Mody, A., and D. Sandri. 2012. "The Eurozone Crisis: How Banks and Sovereigns came to be Joined at the Hip." Economic Policy 27 (70): 199230.

Mohseni, R. M., W. Zhang, and ]. Cao. 2015. “Chaotic Behavior in Monetary Systems: Comparison among Different Types of Taylor Rules." International Journal of Social, Behavioral, Educational, Economic and Management Engineering 9 (8): 2316-2319. 
Montecino, J., and C. Epstein. 2015. Did Quantitative Easing Increase Income Inequality? (No. 28). Institute for New Economic Thinking.

Mourlon-Druol, E. 2014. “Don't Blame the Euro: Historical Reflections on the Roots of the Eurozone Crisis." West European Politics 37 (6): 1282-1296.

Mumtaz, H., and A. Theophilopoulou. 2017. "The Impact of Monetary Policy on Inequality in the UK. An Empirical Analysis." European Economic Review 98: 410-423.

Picault, M., and T. Renault. 2017. “Words are not all Created Equal: A New Measure of ECB Communication." Journal of International Money and Finance 79: 136-156.

Praet, P. 2018. Monetary Policy in a Low Interest Rate Environment. Speech at the Congress of Actuaries, Berlin, 6 June, available at https://www.ecb.europa.eu/press/key/date/2018/html/ecb.sp180606.en.html.

Ramsey, J. B. 1990. “Economic and Financial Data as Nonlinear Processes." In The Stock Market: Bubbles, Volatility, and Chaos. edited by G. P. Dwyer and R.W. Hafer, 81-134. Dordrecht: Springer.

Roberts, G. E. 1911. “The Necessity for a Central Bank." Proceedings of the Academy of Political Science in the City of New York 1 (2): 358-365.

Saka, O., A. M. Fuertes, and E. Kalotychou. 2015. "ECB policy and Eurozone Fragility: Was De Grauwe Right?" Journal of International Money and Finance 54: 168-185.

Schmidt, V. A., and M. Thatcher. 2014. “Why are Neoliberal Ideas so Resilient in Europe's Political Economy?” Critical Policy Studies 8 (3): $340-$ 347.

Serletis, A. 1995. "Random Walks, Breaking Trend Functions, and the Chaotic Structure of the Velocity of Money." Journal of Business $\delta$ Economic Statistics 13 (4): 453-465.

Smith, J., and J. Weeks. 2018. "Bringing Democratic Choice to Europe's Economic Covernance: The EU Treaty Changes We Need, and Why We Need Them." Journal of Self-Governance \& Management Economics 6 (3): 35-95.

Soliman, A. S. 1996. "Transitions from Stable Equilibrium Points to Periodic Cycles to Chaos in a Philips Curve System." Journal of Macroeconomics 18 (1): 139-153.

Solomon, T. H., and Solomon, E. H. 1991. "Money Stability and Control: The Perverse Effects of Feedback Loops." In Electronic Money Flows: The Molding of a New Financial Order, edited by E. H. Solomon, 89-108. Dordrecht: Springer.

Szczerbowicz, U. 2015. "The ECB Unconventional Monetary Policies: Have they Lowered Market Borrowing Costs for Banks and Covernments?" International Journal of Central Banking 11 (4): 91-127.

Talani, L. S. 2016. “The Eurozone Crisis: Between the Clobal Financial Crisis and the Structural Imbalances of the EMU.” In Europe in Crisis, edited by L. S. Talani, 11-35. London: Palgrave Macmillan.

Taylor, ]. B., and J. C. Williams. 2010. "Simple and Robust Rules for Monetary Policy." In Handbook of Monetary Economics, edited by Benjamin M. Friedman and Michael Woodford, Vol. 3, 829-859. North Holland: Elsevier.

Torres, F. 2013. “The EMU's Legitimacy and the ECB as a Strategic Political Player in the Crisis Context." Journal of European Integration 35 (3): 287-300.

Van Riel, A., and A. Schram. 1993. “Weimar Economic Decline, Nazi Economic Recovery, and the Stabilization of Political Dictatorship." The Journal of Economic History 53 (1): 71-105.

Weber, C. S., and B. Forschner. 2014. “ECB: Independence at Risk?" Intereconomics 49 (1): 45-50.

Wilkin, S. 2017. “Managing Political Risk in Advanced Economies." Journal of Risk Management in Financial Institutions 10 (1): 7-11.

Wray, L. R. 2007. “A Post Keynesian View of Central Bank Independence, Policy Targets, and the Rules versus Discretion Debate." Journal of Post Keynesian Economics 30 (1): 119-141. 